\title{
HUBUNGAN LINGKUNGAN FISIK RUMAH DENGAN KEJADIAN TB PARU PADA ORANG DEWASA DI WILAYAH KERJA PUSKESMAS PERAWATAN KUMUN KOTA SUNGAI PENUH
}

\author{
Thrisia Monica \\ Email Korespondensi : thrisiamonica90@gmail.com
}

Disubmit: 30 Desember 2021

Diterima:31 Desember 2021

Diterbitkan: 03 Januari 2022

DOI: https://doi.org/10.33024/mnj.v1i1.5745

\section{ABSTRACT: RELATIONSHIP OF THE PHYSICAL HOME ENVIRONMENT WITH THE INCIDENCE OF PULMONARY TB IN ADULTS IN THE WORKING AREA OF THE COMMUNITY HEALTH CENTER IN KUMUN SUNGAI PENUH CITY}

Introduction: In Indonesia, TB is a major public health problem with approximately $10 \%$ of the total number of TB patients in the world.

Purpose: The purpose of this study was to determine the relationship between the physical environment of the house and the incidence of pulmonary TB in adults in the Working Area of the Kumun Care Health Center in Sungai Penuh City.

Method: The type of this research is descriptive analytical with a case control design, this research has been carried out on 1 - 8 September 2020, with the population and sample divided into two, namely the case population (30 people) and the control population (30 people). Data was collected through observation of the physical environment of the respondent's house, then the data was analyzed using univariate analysis with frequency distribution and bivariate analysis with Chi-Square test.

Result: The results showed that more than half $(53.3 \%)$ of respondents whose lighting did not meet the requirements, (55.0\%) of respondents whose humidity was not good, (58.3\%) of respondents whose ventilation area did not meet the requirements, (73.3\%) ) respondents whose type of floor meets the requirements, $(75.0 \%)$ respondents who use permanent walls, $(51.7 \%)$ respondents whose occupancy density does not meet the requirements. There is a relationship between lighting ( $p$ value $=0.001$ ), humidity relationship ( $p$ value $=0.038)$, ventilation area relationship ( $p$ value $=0.036)$, there is a relationship between occupancy density ( $p$ value $=0.036)$, there is no relationship between floor type ( $p$ value $=0.381)$, there is no relationship between the type of wall $(p$ value $=1,000)$ with the incidence of pulmonary TB in the Kumun Health Center Working Area, Sungai Penuh City in 2020. Conclusion: Based on the results of the study, it is necessary to conduct health education about pulmonary TB, prevention and treatment of pulmonary TB and the conditions of the home environment related to pulmonary TB in the community.

Keywords: Pulmonary TB Incidence, Home Physical Environment 


\section{INTISARI: HUBUNGAN LINGKUNGAN FISIK RUMAH DENGAN KEJADIAN TB PARU PADA ORANG DEWASA DI WILAYAH KERJA PUSKESMAS PERAWATAN KUMUN KOTA SUNGAI PENUH}

Pendahuluan: Di Indonesia, TB merupakan masalah utama kesehatan masyarakat dengan jumlah pasien sekitar 10\% dari total jumlah pasien TB di dunia.

Tujuan: Tujuan penelitian ini untuk mengetahui hubungan lingkungan fisik rumah dengan kejadian TB Paru pada orang dewasa di Wilayah Kerja Puskesmas Perawatan Kumun Kota Sungai Penuh.

Metode: Jenis penelitian ini adalah Deskriptif Analitik dengan desain Case Control, penelitian ini telah dilaksanakan pada tanggal 1 - 8 September 2020, dengan Populasi dan sampel dibagi menjadi dua yaitu populasi kasus (30 orang) dan populasi kontrol (30 orang). Pengumpulan data dilakukan melalui observasi terhadap lingkungan fisik rumah responden, kemudian data dianalisa dengan Analisa univariat dengan Distribusi Frekuansi dan Analisa bivariat dengan Uji Chi-Square.

Hasil: Hasil penelitian didapatkan lebih dari separuh $(53,3 \%)$ responden yang pencahayaan tidak memenuhi syarat, $(55,0 \%)$ responden yang kelembaban tidak baik, $(58,3 \%)$ responden yang luas ventilasi tidak memenuhi syarat, $(73,3 \%)$ responden yang jenis lantai memenuhi syarat, $(75,0 \%)$ responden yang jenis dinding permanen, $(51,7 \%)$ responden yang kepadatan hunian tidak memenuhi syarat. Terdapat hubungan pencahayaan ( $p$ value $=0,001$ ), hubungan kelembaban ( $p$ value $=0,038$ ), hubungan luas ventilasi ( $\mathrm{p}$ value $=0,036)$, terdapat hubungan kepadatan hunian ( $p$ value $=0,036$ ), tidak ada hubungan jenis lantai ( $p$ value $=0,381)$, tidak ada hubungan jenis dinding ( $\mathrm{p}$ value $=1,000$ ) dengan kejadian TB Paru di Wilayah Kerja Puskesmas Kumun Kota Sungai Penuh Tahun 2020.

Kesimpulan; Berpedoman dari hasil penelitian maka perlunya dilakukan penyuluhan kesehatan tentang TB Paru, pencegahan dan pengobatan TB Paru dan kondisi lingkungan rumah yang berhubungan dengan TB Paru pada masyarakat.

Kata Kunci: Kejadian TB Paru, Lingkungan Fisik Rumah

\section{PENDAHULUAN}

World Health Organization

(WHO) menyatakan bahwa situasi

Tuberkulosis (TB) dunia semakin memburuk, dimana jumlah kasus TB meningkat dan banyak yang tidak berhasil disembuhkan. WHO mencanangkan TB sebagai kegawatan dunia (Global Emergency), terutama karena epidemi HIV/AIDS (Human Immunodeficiency Virus/Acquired Immuno Deficiency Syndrome) dan kasus Multi Drug Resistance (MDR) (Sianturi, 2013).

WHO dalam Global Tuberculosis Report 2012 menyatakan terdapat 22 negara dikategorikan sebagai high burden countries terhadap TB Paru, termasuk Indonesia. Indonesia adalah peringkat ke-4 di dunia yang memiliki penderita TB terbesar setelah India, Cina, dan Afrika Selatan. Pada tahun 2011 jumlah penderita TB di seluruh dunia diperkirakan sekitar 8,7 juta. Pada tahun 2011 di Indonesia jumlah kasus TB sekitar 400.000 sampai 500.000 kasus (Sudiantara et all, 2012).

Penyakit Tuberkulosis (TB)

adalah penyakit menular langsung yang disebabkan oleh kuman Mikobakterium tuberkulosis. Sebagian 
besar kuman TB menyerang paru, tetapi dapat juga mengenai organ lain. Sumber penularan adalah penderita TB paru BTA (+) yang dapat menularkan kepada orang di sekelilingnya terutama yang melakukan kontak lama. Setiap satu penderita BTA (+) akan menularkan pada 10-15 orang pertahun (Muaz, 2014).

Di Indonesia, TB merupakan masalah utama kesehatan masyarakat. dengan jumlah pasien sekitar 10\% dari total jumlah pasien TB di dunia. Masih tingginya angka penyakit TB Paru di Indonesia di pengaruhi oleh beberapa faktor antara lain diantaranya rendahnya penghasilan, tingkat kepadatan penduduk, tingkat pendidikan serta rendahnya pengetahuan kesehatan pada masyarakat (Sudiantara et all, 2012).

Berdasarkan data Dinas

Kesehatan Provinsi Jambi didapatkan bahwa terjadi peningkatan perkiraan penderita TB Paru dari tahun 2016 dari 4.900 jumlah suspek yang diperiksa terdapat 3.108 perkiraan penderita TB Paru, tahun 2017 dari 12.551 jumlah suspek yang diperiksa terdapat 6.248 perkiraan penderita TB Paru dan tahun 2019 dari 9.321 jumlah suspek yang diperiksa terdapat 5.560 perkiraan penderita TB Paru (Dinas Kesehatan Provinsi Jambi, 2020).

Di Kota Sungai Penuh tahun 2020 jumlah kasus dan angka penemuan TB Paru BTA+ menurut jenis kelamin, Kecamatan dan Puskesmas Provinsi Jambi terdapat 332 kasus TB Paru BTA+ dimana 230 pada laki-laki dan 102 pada perempuan atau sekitar 16,31\% dari 1.477 suspek TB Paru (Dinas Kesehatan Provinsi Jambi, 2020).

Puskesmas Kumun Kota SungaiPenuh mengalami peningkatan penderita TB Paru setiap tahunnya.
Dimana pada tahun 2016 didapatkan jumlah suspect TB Paru sebesar 275 orang $(1,43 \%)$, BTA+ sebesar 33 orang (0,17\%). Pada tahun 2017 jumlah suspect TB Paru sebesar 282 orang $(1,43 \%)$, BTA + sebesar 41 orang $(0,2 \%)$. Pada tahun 2018 jumlah suspect TB Paru 285 orang $(1,43 \%)$, BTA+ 44 orang $(0,22 \%)$. Sedangkan pada bulan Januari-Maret 2019 ditemukan suspect TB Paru sebesar 47 orang dan BTA+ sebesar 30 orang (Puskesmas Kumun, 2020).

Penyakit tuberkulosis paru yang terjadi pada orang dewasa sebagian besar terjadi pada orangorang yang mendapatkan infeksi primer pada waktu kecil yang tidak ditangani dengan baik. Beberapa faktor yang erat hubungannya dengan terjadinya infeksi basil tuberkulosis adalah adanya sumber penularan, tingkat paparan, virulensi, daya tahan tubuh yang erat kaitannya dengan faktor genetik, faktor faali, jenis kelamin, usia, status gizi, perumahan dan jenis pekerjaan (Fatimah, 2008).

Penelitian (Harfadhilah, Noor dan Sunarka, 2012) yang berjudul analisa faktor risiko lingkungan terhadap kejadian tuberkulosis paru menyimpulkan bahwa ada hubungan antara kepadatan hunian rumah, ventilasi, jenis lantai, jenis dinding, dan kontak serumah dengan keluarga yang TB dengan kejadian tuberkulosis paru. Hasil penelitian (Kurniasari, Suhartono dan Cahyo, 2012 : 203) yang berjudul faktor risiko kejadian Tuberkulosis Paru di Kecamatan Baturetno Kabupaten Wonogiri menyatakan bahwa faktor risiko yang berhubungan dengan kejadian tuberkulosis paru adalah pencahayaan ruangan dan luas ventilasi.

Faktor risiko yang berperan terhadap timbulnya kejadian penyakit tuberkulosis paru dikelompokkan 
menjadi 2 kelompok faktor risiko, yaitu faktor risiko kependudukan (jenis kelamin, umur, status gizi, kondisi sosial ekonomi) dan faktor risiko lingkungan (kepadatan, lantai rumah, ventilasi, pencahayaan, kelembaban, dan ketinggian) (Fatimah, 2008).

Kondisi perumahan di wilayah kerja Puskesmas Kumun masih banyak terdapat rumah yang semi permanen dan tidak permanen. Rumah yang tidak permanen dinding rumahnya yang terbuat dari kayu, lantai yang dari papan atau kayu, ukuran rumah yang kecil dengan penghuni yang banyak, serta kebersihan lingkungan rumah yang kurang terjaga (Puskesmas Kumun, 2020).

Berdasarkan studi pendahuluan yang dilakukan oleh peneliti terhadap beberapa orang pasien di Wilayah Kerja Puskesmas Perawatan Kumun dengan mewawancarai 8 orang didapatkan bahwa 5 dari 8 orang warga msyarakat mengatakan tidak tau bagaimana keadaan rumah yang dapat menyebabkan terjadinya TB Paru, mereka mengatakan ada memiliki ventilasi rumah dan ada sedikit pencahayaan tapi mereka mengatakan tidak tahu bagaimana kondisi pencahayaan yang baik.

Berdasarkan data dan masalah di atas, maka peneliti tertarik untuk melakukan penelitian tantang "Hubungan Lingkungan Fisik Rumah Dengan Kejadian TB Paru Pada Orang Dewasa Di Wilayah Kerja Puskesmas Perawatan Kumun Kota Sungai Penuh Tahun 2020".

\section{METODE PENELITIAN}

Penelitian ini merupakan penelitian survei Analitik Dengan mengunakan desain cross sectional.
Populasi dalam penelitian ini adalah Populasi kasus adalah semua pasien yang terdiagnosa TB Paru di Wilayah Kerja Puskesmas Perawatan Kumun Sungai Penuh 2020 yang berjumlah 30 orang (Puskesmas Perawatan Kumun, 2020).

Dalam penelitian ini, sampel kasus diambil dari seluruh populasi kasus (total populasi) yaitu sebanyak 30 orang, sedangkan kelompok kontrol diambil dari pasien yang tidak terdiagnosa TB Paru, dengan perbandingan 1 : 1 antara sampel kasus dan sampel kontrol tanpa sepadan (unmatching) sebanyak 30 orang. Jadi jumlah sampel secara keseluruhan adalah 60 orang.

Teknik pengambilan sampel dilakukan dengan accident sampling yaitu dilakukan dengan pengambilan kasus atau respondent yang kebetulan ada atau tersedia disuatu tempat sesuai dengan konteks penelitian (Notoatmodjo, 2012). Penelitian dilaksanaan di Wilayah Kerja Pukesmas Perawatan Kumun Di Sungai penuh pada Bulan September 2020. Jenis penelitian yang digunakan adalah penelitian Deskriptif Analitik. Penelitian ini didesain secara Case Control. Desain penelitian merupakan penelitian yang disusun sedemikian rupa sehingga peneliti dapat memperoleh jawaban terhadap pertanyaan penelitian. Penelitian ini bertujuan untuk mengidentifikasi kelompok penyakit atau efek tertentu (kasus) dan kelompok tanpa efek (kontrol), kemudian secara retrospektif diteliti faktor resikonya (Riyanto, $2011: 89$ ).

Tempat penelitian dilakukan di Wilayah Kerja Puskesmas Perawatan Kumun Kota Sungai Penuh. Penelitian ini telah dilaksanakan pada tanggal 1 8 September 2020. yang berjumlah 30 orang (Puskesmas Perawatan Kumun, 
2020). Dalam penelitian ini, sampel kasus diambil dari seluruh populasi kasus (total populasi) yaitu sebanyak 30 orang, sedangkan kelompok kontrol diambil dari pasien yang tidak terdiagnosa TB Paru, dengan perbandingan $1: 1$ antara sampel kasus dan sampel kontrol tanpa sepadan (unmatching) sebanyak 30 orang. Jadi jumlah sampel secara keseluruhan adalah 60 orang.

HASIL PENELITIAN

Analisa Univariat

*Distribusi Frekuensi Karakteristik Responden

Tabel 1

Distribusi Frekuensi Responden Berdasarkan Kejadian TB Paru di Wilayah Kerja Puskesmas Kumun Tahun 2020

\begin{tabular}{ccc}
\hline Kejadian TB Paru & f & $\%$ \\
\hline Kasus & 30 & 50,0 \\
Kontrol & 30 & 50,0 \\
\hline Jumlah & 60 & 100 \\
\hline
\end{tabular}

Berdasarkan tabel 1 dapat dilihat bahwa 30 responden TB Paru (kasus) dan 30 responden bukan TB
Paru (kontrol) di Wilayah Kerja Puskesmas Perawatan Kumun Tahun 2020.

Tabel 2

Distribusi Frekuensi Responden Berdasarkan Pencahayaan di Wilayah Kerja Puskesmas Kumun Tahun 2020

\begin{tabular}{ccc}
\hline Pencahayaan & f & $\%$ \\
\hline Tidak Memenuhi Syarat & 32 & 53,3 \\
Memenuhi Syarat & 28 & 46,7 \\
\hline Jumlah & 60 & 100 \\
\hline
\end{tabular}

Berdasarkan tabel 2 dapat dilihat lebih dari separuh $(53,3 \%)$ responden yang pencahayaan rumahnya tidak memenuhi syarat di Wilayah Kerja Puskesmas Kumun Tahun 2020.

Tabel 3

Distribusi Frekuensi Responden Berdasarkan Kelembaban di Wilayah Kerja Puskesmas Kumun Tahun 2020

\begin{tabular}{ccc} 
Kelembaban & f & $\%$ \\
\hline Tidak Baik & 33 & 55,0 \\
Baik & 27 & 45,0 \\
\hline Jumlah & 60 & 100 \\
\hline
\end{tabular}

Berdasarkan tabel 3 dapat dilihat lebih dari separuh $(55,0 \%)$ responden yang kelembaban rumahnya tidak baik di Wilayah Kerja Puskesmas Kumun Tahun 2020. 
Tabel 4

Distribusi Frekuensi Responden Berdasarkan Luas Ventilasi di Wilayah Kerja Puskesmas Kumun Tahun 2020

\begin{tabular}{ccc}
\hline Luas Ventilasi & f & $\%$ \\
\hline Tidak Memenuhi Syarat & 35 & 58,3 \\
Memenuhi Syarat & 25 & 41,7 \\
\hline Jumlah & 60 & 100 \\
\hline
\end{tabular}

Berdasarkan tabel 4 dapat dilihat lebih dari separuh $(58,3 \%)$ responden yang luas ventilasi rumahnya tidak memenuhi syarat di Wilayah Kerja Puskesmas Kumun Tahun 2020.

Tabel 5

Distribusi Frekuensi Responden Berdasarkan Jenis Lantai di Wilayah Kerja Puskesmas Kumun Sungai Penuh Tahun 2020

\begin{tabular}{ccc}
\hline Jenis Lantai & $\mathbf{f}$ & $\%$ \\
\hline Tidak Memenuhi Syarat & 16 & 26,7 \\
Memenuhi Syarat & 44 & 73,3 \\
\hline Jumlah & 60 & 100 \\
\hline
\end{tabular}

Berdasarkan tabel 5 dapat dilihat lebih dari separuh $(73,3 \%)$ responden yang jenis lantai rumahnya memenuhi syarat di Wilayah Kerja Puskesmas Kumun Sungai Penuh Tahun 2020.

Tabel 6

Distribusi Frekuensi Responden Berdasarkan Jenis Dinding di Wilayah Kerja Puskesmas Kumun Sungai Penuh Tahun 2020

\begin{tabular}{ccc}
\hline Jenis Dinding & $\mathbf{f}$ & $\%$ \\
\hline Tidak Permanen & 15 & 25,0 \\
Permanen & 45 & 75,0 \\
\hline Jumlah & 60 & 100 \\
\hline
\end{tabular}

Berdasarkan tabel 6 dapat dilihat lebih d

$$
\text { ari separuh }(75,0 \%) \text { responden }
$$

permanen di Wilayah Kerja Puskesmas Kumun Di Sungai Penuh Tahun 2020. yang jenis dinding rumahnya

Tabel 7

Distribusi Frekuensi Responden Berdasarkan Kepadatan Hunian di Wilayah Kerja Puskesmas Kumun Tahun 2020

\begin{tabular}{ccc} 
Kepadatan Hunia & $\mathbf{f}$ & $\%$ \\
\hline Tidak Memenuhi Syarat & 31 & 51,7 \\
Memenuhi Syarat & 29 & 48,3 \\
\hline Jumlah & 60 & 100 \\
\hline
\end{tabular}


Berdasarkan tabel 7 dapat dilihat lebih dari separuh $(51,7 \%)$ responden yang kepadatan hunian rumahnya tidak memenuhi syarat di Wilayah Kerja Puskesmas Kumun Di Kota Sungai Penuh Tahun 2020.

\section{Analisa Bivariat \\ * Hubungan Pencahayaan dengan Kejadian TB Paru \\ Tabel 8}

Hubungan Pencahayaan dengan Kejadian TB Paru di Wilayah Kerja Puskesmas Kumun Sungai Penuh Tahun 2020

\begin{tabular}{|c|c|c|c|c|c|c|c|c|}
\hline \multirow{3}{*}{ Pencahayaan } & \multicolumn{4}{|c|}{ Status Responden } & \multirow{2}{*}{\multicolumn{2}{|c|}{ Jumlah }} & \multirow{3}{*}{$\begin{array}{c}\mathrm{p}- \\
\text { value }\end{array}$} & \multirow{3}{*}{$\begin{array}{c}\text { OR } \\
(95 \% \\
\mathrm{CI})\end{array}$} \\
\hline & \multicolumn{2}{|c|}{ Kasus } & \multicolumn{2}{|c|}{ Kontrol } & & & & \\
\hline & $f$ & $\%$ & $f$ & $\%$ & $f$ & $\%$ & & \\
\hline Tidak Memenuhi Syarat & 23 & 71,9 & 9 & 28,1 & 32 & 100 & & 7,667 \\
\hline Memenuhi Syarat & 7 & 25,0 & 21 & 75,0 & 28 & 100 & 0,001 & $(2,424-$ \\
\hline Jumlah & 30 & 50,0 & 30 & 50,0 & 60 & 100 & & $2,4245)$ \\
\hline
\end{tabular}

Berdasarkan tabel 8 diketahui dari 30 responden yang hasil TB Paru, sebanyak 23 responden $(71,9 \%)$ memiliki pencahayaan rumahnya yang tidak memenuhi syarat dan hanya 7 responden $(25,0 \%)$ yang memiliki pencahayaan rumahnya yang memenuhi syarat. Hasil uji statistik diperoleh nilai $p$ value $=0,001(p<$ $0,05)$ hal ini berarti berarti $\mathrm{H}_{\mathrm{a}}$ diterima dan $\mathrm{H}_{0}$ ditolak serta ada hubungan yang signifikan antara pencahayaan dengan kejadian TB Paru di Wilayah Kerja Puskesmas Kumun Sungai Penuh Tahun 2020.

Hasil analisis diperoleh pula nilai $\mathrm{OR}=7,667$ artinya responden yang memiliki pencahayaan rumah yang tidak memenuhi syarat beresiko 7,667 kali untuk menderita TB Paru dibandingkan dengan responden yang pencahayaan rumahnya memenuhi syarat.

\section{Hubungan Kelembaban dengan Kejadian TB Paru \\ Tabel 9 \\ Hubungan Kelembaban dengan Kejadian TB Paru di Wilayah Kerja Puskesmas Kumun Sungai Penuh Tahun 2020

\begin{tabular}{|c|c|c|c|c|c|c|c|c|}
\hline \multirow{3}{*}{ Kelemababan } & \multicolumn{4}{|c|}{ Status Responden } & \multirow{2}{*}{\multicolumn{2}{|c|}{ Jumlah }} & \multirow{3}{*}{$\begin{array}{c}\text { P- } \\
\text { value }\end{array}$} & \multirow{3}{*}{$\begin{array}{c}\text { OR } \\
(95 \% \\
\mathrm{CI})\end{array}$} \\
\hline & \multicolumn{2}{|c|}{ Kasus } & \multicolumn{2}{|c|}{ Kontrol } & & & & \\
\hline & $f$ & $\%$ & $f$ & $\%$ & $f$ & $\%$ & & \\
\hline Tidak Baik & 21 & 63,6 & 12 & 36,4 & 33 & 100 & & 3,500 \\
\hline Baik & 9 & 33,3 & 18 & 66,7 & 27 & 100 & 0,038 & $(1,201$ - \\
\hline Jumlah & 30 & 50,0 & 30 & 50,0 & 60 & 100 & & $10,196)$ \\
\hline
\end{tabular}

Berdasarkan tabel 9 diketahui dari 30 responden yang hasil TB Paru, sebanyak 21 responden $(63,6 \%)$ yang kelembaban rumahnya tidak baik dan hanya 9 responden $(33,3 \%)$ yang kelembaban rumahnya baik. Hasil uji statistik diperoleh nilai $p$ value $=0,038$ $(p<0,05)$ hal ini berarti berarti $\mathrm{H}_{\mathrm{a}}$ diterima dan $\mathrm{H}_{0}$ ditolak serta ada hubungan yang signifikan antara kelembaban dengan kejadian TB Paru di Wilayah Kerja Puskesmas Kumun Sungai Penuh Tahun 2020. 
Hasil analisis diperoleh pula nilai $\mathrm{OR}=3,500$ artinya responden yang memiliki kelembaban rumah yang tidak baik beresiko 3,500 kali untuk menderita TB Paru dibandingkan dengan responden yang kelambaban rumahnya baik.

Hubungan Luas Ventilasi dengan Kejadian TB Paru

Tabel 10 Hubungan Luas Ventilasi dengan Kejadian TB Paru di Wilayah Kerja Puskesmas Kumun Sungai Penuh Tahun 2020

\begin{tabular}{|c|c|c|c|c|c|c|c|c|}
\hline \multirow{3}{*}{ Luas Ventilasi } & \multicolumn{4}{|c|}{ Status Responden } & \multirow{2}{*}{\multicolumn{2}{|c|}{ Jumlah }} & \multirow{3}{*}{$\begin{array}{c}\mathrm{p}- \\
\text { value }\end{array}$} & \multirow{3}{*}{$\begin{array}{c}\text { OR }(95 \% \\
\mathrm{Cl})\end{array}$} \\
\hline & \multicolumn{2}{|c|}{ Kasus } & \multicolumn{2}{|c|}{ Kontrol } & & & & \\
\hline & $f$ & $\%$ & f & $\%$ & f & $\%$ & & \\
\hline Tidak Memenuhi Syarat & 22 & 62,9 & 13 & 37,1 & 35 & 100 & \multirow{3}{*}{0,036} & \multirow{3}{*}{$\begin{array}{c}3,596 \\
(1,216- \\
10,638)\end{array}$} \\
\hline Memenuhi Syarat & 8 & 32,0 & 17 & 68,0 & 25 & 100 & & \\
\hline Jumlah & 30 & 50,0 & 30 & 50,0 & 60 & 100 & & \\
\hline
\end{tabular}

Berdasarkan tabel 10 diketahui dari 30 responden yang hasil TB Paru, sebanyak 22 responden $(62,9 \%)$ yang luas ventilasi rumahnya tidak memenuhi syarat dan hanya sebanyak 8 responden $(32,0 \%)$ yang luas ventilasi rumahnya memenuhi syarat. Hasil uji statistik diperoleh nilai $p$ value $=0,036(p<0,05)$ hal ini berarti berarti $\mathrm{H}_{\mathrm{a}}$ diterima dan $\mathrm{H}_{0}$ ditolak serta ada hubungan yang

signifikan antara luas ventilasi dengan kejadian TB Paru di Wilayah Kerja Puskesmas Kumun Tahun 2020.

Hasil analisis diperoleh pula nilai $\mathrm{OR}=3,596$ artinya responden yang memiliki luas ventilasi yang tidak memenuhi syarat beresiko 3,596 kali untuk menderita TB Paru dibandingkan dengan responden yang luas ventilasi yang memenuhi syarat.

Hubungan Jenis Lantai dengan Kejadian TB Paru

Tabel 11 Hasil analisis bivariat hubungan jenis lantai dengan kejadian TB Paru dapat dilihat pada tabel berikut :

Hubungan Jenis Lantai dengan Kejadian TB Paru di Wilayah Kerja Puskesmas Kumun Sungai Penuh Tahun 2020

\begin{tabular}{|c|c|c|c|c|c|c|c|c|}
\hline \multirow{3}{*}{ Jenis Lantai } & \multicolumn{4}{|c|}{ Status Responden } & \multirow{2}{*}{\multicolumn{2}{|c|}{ Jumlah }} & \multirow{3}{*}{$\begin{array}{c}\mathrm{p}- \\
\text { value }\end{array}$} & \multirow{3}{*}{$\begin{array}{c}\text { OR }(95 \% \\
\text { CI) }\end{array}$} \\
\hline & \multicolumn{2}{|c|}{ Kasus } & \multicolumn{2}{|c|}{ Kontrol } & & & & \\
\hline & f & $\%$ & f & $\%$ & f & $\%$ & & \\
\hline Tidak Memenuhi Syarat & 10 & 62,5 & 6 & 37,5 & 16 & 100 & & 2,000 \\
\hline Memenuhi Syarat & 20 & 45,5 & 24 & 54,5 & 44 & 100 & 0,381 & $(0,619$ \\
\hline Jumlah & 30 & 50,0 & 30 & 50,0 & 60 & 100 & & $6,465)$ \\
\hline
\end{tabular}

Berdasarkan tabel 11 diketahui dari 30 responden yang hasil TB Paru, sebanyak 10 responden $(62,5 \%)$ yang jenis lantai rumahnya tidak memenuhi syarat dan sebanyak 20 responden $(45,5 \%)$ yang jenis lantai rumahnya memenuhi syarat. Hasil uji statistik diperoleh nilai $p$ value $=0,381$ $(p<0,05)$ hal ini berarti berarti $\mathrm{H}_{\mathrm{a}}$ ditolak dan $\mathrm{H}_{0}$ diterima serta tidak ada hubungan yang signifikan antara jenis lantai dengan kejadian TB Paru di 
Wilayah Kerja Puskesmas Kumun Sungai Penuh Tahun 2020.

Hasil analisis diperoleh pula nilai $\mathrm{OR}=2,000$ artinya responden yang memiliki jenis lantai yang tidak memenuhi syarat beresiko 2,000 kali untuk menderita TB Paru dibandingkan dengan responden yang jenis lantai yang memenuhi syarat.

Hubungan Jenis Dinding dengan Kejadian TB Paru

Tabel 12 Hubungan Jenis Dinding dengan Kejadian TB Paru di Wilayah Kerja Puskesmas Kumun Sungai Penuh Tahun 2020

\begin{tabular}{|c|c|c|c|c|c|c|c|c|}
\hline \multirow{3}{*}{ Jenis Dinding } & \multicolumn{4}{|c|}{ Status Responden } & \multirow{2}{*}{\multicolumn{2}{|c|}{ Jumlah }} & \multirow{3}{*}{$\begin{array}{c}\mathrm{p}- \\
\text { value }\end{array}$} & \multirow{3}{*}{$\begin{array}{c}\text { OR }(95 \% \\
\text { CI) }\end{array}$} \\
\hline & \multicolumn{2}{|c|}{ Kasus } & \multicolumn{2}{|c|}{ Kontrol } & & & & \\
\hline & $f$ & $\%$ & $f$ & $\%$ & $f$ & $\%$ & & \\
\hline Tidak Permanen & 7 & 46,7 & 8 & 53,3 & 15 & 100 & & 0,837 \\
\hline Permanen & 23 & 51,1 & 22 & 48,9 & 45 & 100 & 1,000 & $(0,260-$ \\
\hline Jumlah & 30 & 50,0 & 30 & 50,0 & 60 & 100 & & $2,699)$ \\
\hline
\end{tabular}

Berdasarkan tabel 12 diketahui dari 30 responden yang hasil TB Paru, sebanyak 7 responden $(46,7 \%)$ yang jenis dinding rumahnya tidak permanen dan sebanyak 23 responden $(51,1 \%)$ yang jenis dinding rumahnya permanen. Hasil uji statistik diperoleh nilai $p$ value $=1,000(p<$ $0,05)$ hal ini berarti berarti $\mathrm{H}_{\mathrm{a}}$ ditolak dan $\mathrm{H}_{0}$ diterima serta tidak ada hubungan yang signifikan antara jenis

dinding dengan kejadian TB Paru di Wilayah Kerja Puskesmas Kumun Sungai Penuh Tahun 2020.

Hasil analisis diperoleh pula nilai $\mathrm{OR}=0,837$ artinya responden yang memiliki jenis dinding yang tidak permanen beresiko 0,837 kali untuk menderita TB Paru dibandingkan dengan responden yang jenis dinding permanen.

Hubungan Kepadatan Hunian dengan Kejadian TB Paru

Tabel 13 Hubungan Kepadatan Hunian dengan Kejadian TB Paru di Wilayah Kerja Puskesmas Kumun Sungai Penuh Tahun 2020

\begin{tabular}{|c|c|c|c|c|c|c|c|c|}
\hline \multirow{3}{*}{ Kepadatan Hunian } & \multicolumn{4}{|c|}{ Status Responden } & \multirow{2}{*}{\multicolumn{2}{|c|}{ Jumlah }} & \multirow{3}{*}{$\begin{array}{c}\mathrm{p}- \\
\text { value }\end{array}$} & \multirow{3}{*}{$\begin{array}{c}\text { OR } \\
(95 \% \\
\text { CI) }\end{array}$} \\
\hline & \multicolumn{2}{|c|}{ Kasus } & \multicolumn{2}{|c|}{ Kontrol } & & & & \\
\hline & $f$ & $\%$ & $f$ & $\%$ & $f$ & $\%$ & & \\
\hline Tidak Memenuhi Syarat & 23 & 74,2 & 8 & 25,8 & 31 & 100 & & 9,036 \\
\hline Memenuhi Syarat & 7 & 24,1 & 22 & 75,9 & 29 & 100 & 0,000 & $(2,802-$ \\
\hline Jumlah & 30 & 50,0 & 30 & 50,0 & 60 & 100 & & $29,134)$ \\
\hline
\end{tabular}

Berdasarkan tabel 13 diketahui dari 30 responden yang hasil TB Paru, sebanyak 23 responden $(74,2 \%)$ yang kepadatan hunian rumahnya tidak memenuhi syarat dan sebanyak 7 responden $(24,1 \%)$ yang kepadatan hunian rumahnya memenuhi syarat. Hasil uji statistik diperoleh nilai $p$ value $=0,000(p<$
0,05) hal ini berarti berarti $\mathrm{H}_{\mathrm{a}}$ diterima dan $\mathrm{H}_{0}$ ditolak serta ada hubungan yang signifikan antara kepadatan hunian dengan kejadian TB Paru di Wilayah Kerja Puskesmas Kumun Sungai Penuh Tahun 2020.

Hasil analisis diperoleh pula nilai $\mathrm{OR}=9,036$ artinya responden yang memiliki kepadatan hunian 
rumah yang tidak memenuhi syarat beresiko 9,036 kali untuk menderita TB Paru dibandingkan dengan

\section{PEMBAHASAN}

Karakteristik Responden

Pencahayaan

Hasil analisis distribusi frekuensi responden berdasarkan tabel 1 didapatkan dari 60 orang responden terdapat lebih dari separuh $(53,3 \%)$ responden yang pencahayaan rumahnya tidak memenuhi syarat di Wilayah Kerja Puskesmas Kumun Sungai Penuh Tahun 2020.

\section{Kelembaban}

Hasil analisis distribusi frekuensi responden berdasarkan tabel 2 didapatkan dari 60 orang responden terdapat lebih dari separuh $(55,0 \%)$ responden yang kelembaban rumahnya tidak baik di Wilayah Kerja Puskesmas Kumun Sungai Penuh Tahun 2020.

Menurut analisa peneliti, lebih dari separuh responden yang kelembabannya tidak baik. Hal ini disebabkan karena sebagian besar rumah responden memiliki drainase dan saluran air disekeliling rumah yang tidak baik yang membuat air sering tergenang dan membuat lahan disekitar saluran air tersebut lembab dan lantai yang tidak kantai kedap air yang membuat lantai lembab. Hal ini didukung dari hasil observasi peneliti terhadap 5 syarat kelembaban rumah. Dimana terdapat $80 \%$ rumah responden yang lantainya tidak kedap air sehingga membuat lantai lembab. Terdapat $60 \%$ rumah responden yang drainase dan saluran air disekeliling rumah yang tidak baik.

\section{Luas Ventilasi}

Hasil analisis distribusi frekuensi responden berdasarkan tabel 3 didapatkan dari 60 orang responden yang kepadatan hunian yang memenuhi syarat.

responden terdapat lebih dari separuh $(58,3 \%)$ responden yang luas ventilasi rumahnya tidak memenuhi syarat di Wilayah Kerja Puskesmas Kumun Sungai Penuh Tahun 2020.

Menurut analisa peneliti, lebih dari separuh responden yang luas ventilasi rumah tidak memenuhi syarat. Hal ini disebabkan karena sebagian besar ventilasi rumah responden berasal dari ventilasi diatas jendela, ventilasi diatas pintu rumah yang total luasnya < 10\% dari luas lantai. Dan juga terdapat rumah yang ventilasinya tertutup dengan kaca sehingga seharusnya ventilasi sebagai tempat bertukarnya udara dari dalam dan keluar rumah tidak dapat berfungsi dengan baik. Hal ini didukung dari hasil observasi peneliti terhadap ukuran ventilasi rumah responden. Dimana sebagian besar ukuran ventilasi yang berada diatas jendela $0,5 \times 2,5 \mathrm{M}=1,25 \mathrm{M}^{2}$ ditambah luas ventilasi diatas pintu $0,5 \times 1 \mathrm{M}=$ $0,5 \mathrm{M}^{2}$ jadi total luas ventilasi $1,75 \mathrm{M}^{2}$. Sedangkan luas lantai sebagian besar 4 x $5 \mathrm{~m}=20 \mathrm{M}^{2}$ yang artinya ventilasi kurang dari $10 \%$ dari luas lantai $(10 \% \mathrm{X}$ $20 M^{2}=2 M^{2}$ ).

Jenis Lantai

Hasil analisis distribusi frekuensi responden berdasarkan tabel 4 didapatkan dari 60 orang responden terdapat lebih dari separuh $(73,3 \%)$ responden yang jenis lantai rumahnya memenuhi syarat di Wilayah Kerja Puskesmas Kumun Sungai Penuh Tahun 2020.

Menurut analisa peneliti, lebih dari separuh responden yang jenis lantai rumahnya tidak memenuhi syarat. Hal ini disebabkan sebagian 
besar lantai rumah responden terbuat dari papan dan bahkan masih ada yang lantai rumahnya tanah yang hanya dilapisi dengan tikar seadanya sehingga tidak kedap air, tidak mudah dibersihkan, lembab dan berdebu. Hal ini didukung dari hasil observasi peneliti terhadap keadaan lantai rumah responden, dimana terdapat $5 \%$ dari responden yang lantainya tidak mudah dibersihkan, terdapat 25\% dari responden yang lantainya lembab, dan terdapat $25 \%$ dari responden yang lantainya berdebu.

Jenis Dinding

Hasil analisis distribusi frekuensi responden berdasarkan tabel 5 didapatkan dari 60 orang responden terdapat lebih dari separuh $(75,0 \%)$ responden yang jenis dinding rumahnya permanen di Wilayah Kerja Puskesmas Kumun Tahun 2020.

Menurut analisa peneliti, lebih dari separuh responden yang jenis dindingnya permanen. Hal ini disebabkan sebagian besar jenis dinding rumah responden sudah permanen yang terbuat dari bahan semen sehingga mudah untuk dibersihkan dan mudah dibersihkan dari debu dan air. Hanya sebagian kecil dari responden yang jenis dindingnya tidak permanen yang terbuat dari papap yang disusun rapat. Hal ini didukung dari hasil observasi peneliti terhadap jenis dinding rumah responden. Dimana jenis dinding rumah responden sudah terbuat dari semen sehingga mudah dibersihkan. Meskipun masih ada sedikit responden yang jenis dinding rumahnya terbuat dari papan tapi sudah disusun dengan rapat.

\section{Kepadatan Hunian}

Hasil analisis distribusi
frekuensi responden berdasarkan tabel 6 didapatkan dari 60 orang responden terdapat lebih dari separuh
$(51,7 \%)$ responden yang kepadatan hunian rumahnya tidak memenuhi syarat di Wilayah Kerja Puskesmas Kumun Sungai Penuh Tahun 2020.

Menurut analisa peneliti, lebih dari separuh responden yang kepadatan hunian rumahnya tidak memenuhi syarat. Hal ini disebabkan karena sebagian besar responden syarat kebutuhan ruangan $9 \mathrm{M}^{2}$ per orang tidak terpenuhi dengan ketinggian langit-langit kurang dari 2,8 M. Sebagian besar rumah responden dalam satu rumah terdiri dari 5 sampai 6 orang sedangkan luas ruangan rumah $5 \times 8 \mathrm{~m}=40 \mathrm{M}^{2}$ yang artinya satu orang hanya mendapat 7 sampai 8 M2 sehingga tidak memenuhi syarat kepadatan hunian rumah yang baik. Hal ini didukung dari hasil observasi dan wawancara peneliti dengan responden yang mana responden mengatakan yang tinggal dirumahnya terdiri dari responden itu sendiri, istri, 3 orang anaknya dan mertunya sehingga berjumlah 6 orang dalam satu rumah. Sedangkan luas ruangan rumah yang mereka tinggali hanya $5 \times 8 \mathrm{~m}=40 \mathrm{M}^{2}$.

1. Hubungan Pencahayaan dengan Kejadian TB Paru

Berdasarkan tabel 8 diketahui dari 30 responden yang hasil TB Paru, sebanyak 23 responden (71,9\%) memiliki pencahayaan rumahnya yang tidak memenuhi syarat dan hanya 7 responden $(25,0 \%)$ yang memiliki pencahayaan rumahnya yang memenuhi syarat. Hasil uji statistik diperoleh nilai $p$ value $=0,001(p<$ $0,05)$ hal ini berarti berarti $\mathrm{H}_{\mathrm{a}}$ diterima dan $\mathrm{H}_{0}$ ditolak serta ada hubungan yang signifikan antara pencahayaan dengan kejadian TB Paru di Wilayah Kerja Puskesmas Kumun Tahun 2020.

Hasil analisis diperoleh pula nilai $\mathrm{OR}=7,667$ artinya responden yang memiliki pencahayaan rumah 
yang tidak memenuhi syarat beresiko 7,667 kali untuk menderita TB Paru dibandingkan dengan responden yang pencahayaan rumahnya memenuhi syarat.

Menurut analisa peneliti, responden yang menderita TB Paru yaitu pada kelompok kasus sebagian besar terjadi pada rumah yang pencahayaannya tidak memenuhi syarat. Hal ini disebabkan karena pencahayaan yang tidak cukup atau tidak memenuhi syarat tidak mampu membunuh bakteri-bakteri khusunya Mycobacterium Tuberculosis sehingga rumah yang kurang pencahayaan meningkatkan perkembangan bakteri tersebut yang akhirnya berdampak bagi kesehatan penghuninya.

Kejadian TB Paru ini juga dipengaruhi oleh umur responden yang mana pada kelompok kasus lebih banyak responden yang berumur > 40 tahun $(50,0 \%)$ ditambah lagi dengan pekerjaan yang sebagian besar $(63,3 \%)$ responden dengan pekerjaan petani yang memiliki daya tahan tubuh yang berkurang seiring dengan pertambahan usia dan beratnya pekerjaan yang mereka lakukan sehari-hari.

2. Hubungan Kelembaban dengan Kejadian TB Paru

Berdasarkan tabel 9 diketahui dari 30 responden yang hasil TB Paru, sebanyak 21 responden $(63,6 \%)$ yang kelembaban rumahnya tidak baik dan hanya 9 responden $(33,3 \%)$ yang kelembaban rumahnya baik. Hasil uji statistik diperoleh nilai $p$ value $=0,038$ $(p<0,05)$ hal ini berarti berarti $\mathrm{H}_{\mathrm{a}}$ diterima dan $\mathrm{H}_{0}$ ditolak serta ada hubungan yang signifikan antara kelembaban dengan kejadian TB Paru di Wilayah Kerja Puskesmas Kumun Sungai Penuh Tahun 2020.

Hasil analisis diperoleh pula nilai $\mathrm{OR}=3,500$ artinya responden yang memiliki kelembaban rumah yang tidak baik beresiko 3,500 kali untuk menderita TB Paru dibandingkan dengan responden yang kelambaban rumahnya baik.

Menurut analisa peneliti, responden yang menderita TB Paru yaitu pada kelompok kasus sebagian besar terjadi pada rumah yang kelembabannya tidak baik. Hal ini disebabkan kelembaban ruangan yang tidak baik merupakan media yang baik untuk tempat berkembang biaknya bakteri dan kuman khususnya Mycobacterium Tuberculosis sehingga rumah yang kelembabannya tidak baik menjadi tempat tumbuh dan berkembangnya bakteri TB yang akan berdampak pada kesehatan penghuninya. Bakteri TB akan mudah menyerang penghuninya yang memiliki daya tahan tubuh yang berkurang seiring dengan pertambahan usia dan beban pekerjaan yang berat yang mana pada kelompok kasus lebih banyak responden yang berumur $>40$ tahun $(50,0 \%)$ dengan pekerjaan yang sebagian besar $(63,3 \%)$ responden dengan pekerjaan petani.

3. Hubungan Luas Ventilasi dengan Kejadian TB Paru

Berdasarkan tabel 10 diketahui dari 30 responden yang hasil TB Paru, sebanyak 22 responden $(62,9 \%)$ yang luas ventilasi rumahnya tidak memenuhi syarat dan hanya sebanyak 8 responden $(32,0 \%)$ yang luas ventilasi rumahnya memenuhi syarat. Hasil uji statistik diperoleh nilai $p$ value $=0,036(p<0,05)$ hal ini berarti berarti $\mathrm{H}_{a}$ diterima dan $\mathrm{H}_{0}$ ditolak serta ada hubungan yang signifikan antara luas ventilasi dengan kejadian TB Paru di Wilayah Kerja Puskesmas Kumun Sungai Penuh Tahun 2020.

Hasil analisis diperoleh pula nilai $\mathrm{OR}=3,596$ artinya responden 
yang memiliki luas ventilasi yang tidak memenuhi syarat beresiko 3,596 kali untuk menderita TB Paru dibandingkan dengan responden yang luas ventilasi yang memenuhi syarat.

Menurut analisa peneliti, responden yang menderita TB Paru yaitu pada kelompok kasus sebagian besar terjadi pada rumah yang ventilasinya tidak memenuhi syarat. Hal ini disebabkan ventilasi yang tidak memenuhi syarat tidak mampu berfungsi sebagai pengurai kelembaban, tidak memaksimalkan masuknya sinar matahari, dan tidak maksimal dalam betukarnya sirkulasi udara sehingga rumah yang ventilasinya tidak memenuhi syarat tidak mampu membunuh bakteri Mycobacterium Tuberculosis sehingga rumah menjadi tempat berkembangnya penyakit TB. Jika daya tahan tubuh penghuninya berkurang maka akan mudah terjangkit penyakit TB Paru, hal ini didukung dengan umur responden pada kelompok kasus yang sebagain besar berumur > 40 tahun yang memiliki daya tahan tubuh yang berkurang.

4. Hubungan Jenis Lantai dengan Kejadian TB Paru

Berdasarkan tabel 11 diketahui dari 30 responden yang hasil TB Paru, sebanyak 10 responden $(62,5 \%)$ yang jenis lantai rumahnya tidak memenuhi syarat dan sebanyak 20 responden $(45,5 \%)$ yang jenis lantai rumahnya memenuhi syarat. Hasil uji statistik diperoleh nilai $p$ value $=0,381$ $(p<0,05)$ hal ini berarti berarti $\mathrm{H}_{\mathrm{a}}$ ditolak dan $\mathrm{H}_{0}$ diterima serta tidak ada hubungan yang signifikan antara jenis lantai dengan kejadian TB Paru di Wilayah Kerja Puskesmas Kumun Sungai Penuh Tahun 2020.

Hasil analisis diperoleh pula nilai $\mathrm{OR}=2,000$ artinya responden yang memiliki jenis lantai yang tidak memenuhi syarat beresiko 2,000 kali untuk menderita TB Paru dibandingkan dengan responden yang jenis lantai yang memenuhi syarat.

Menurut analisa peneliti, responden yang menderita TB Paru yaitu pada kelompok kasus sebagian kecil yang terjadi pada rumah yang lantainya tidak memenuhi syarat sedangkan sebagian besarnya memiliki lantai yang memenuhi syarat. Hal ini disebabkan karena responden yang menderita TB Paru pada rumah yang jenis lantainya permanen kurang memperhatikan kebersihan lantai rumahnya seperti rumah yang jarang disapu dan berdebu sehingga memungkinkan juga untuk berkembangnya bakteri Mycobacterium Tuberculosis, ditambah lagi dengan umur responden pada kelompok kasus yang lebih banyak berumus > 40 tahun yang memiliki daya tahan tubuh yang semakin berkurang dengan pertambahan usia memudahkan bakteri TB untuk menyerang.

5. Hubungan Jenis Dinding dengan Kejadian TB Paru

Berdasarkan tabel 12 diketahui dari 30 responden yang hasil TB Paru, sebanyak 7 responden $(46,7 \%)$ yang jenis dinding rumahnya tidak permanen dan sebanyak 23 responden $(51,1 \%)$ yang jenis dinding rumahnya permanen. Hasil uji statistik diperoleh nilai $p$ value $=1,000(p<$ $0,05)$ hal ini berarti berarti $\mathrm{H}_{\mathrm{a}}$ ditolak dan $\mathrm{H}_{0}$ diterima serta tidak ada hubungan yang signifikan antara jenis dinding dengan kejadian TB Paru di Wilayah Kerja Puskesmas Kumun Tahun 2020.

Hasil analisis diperoleh pula nilai $O R=0,837$ artinya responden yang memiliki jenis dinding yang tidak permanen beresiko 0,837 kali untuk 
menderita TB Paru dibandingkan dengan responden yang jenis dinding permanen.

Menurut analisa peneliti, responden yang menderita TB Paru yaitu pada kelompok kasus sebagian kecil yang terjadi pada rumah yang jenis dindingnya tidak permanen sedangkan sebagian besarnya memiliki jenis dinding yang permanen. Hal ini disebabkan karena ruangan yang jarang dibuka dan tidak terkena matahari sehingga dapat menyebabkan tingginya kelembaban sehingga dinding yang permanenpun dapat ditumbuhi oleh mikroorganisme seperti Mycobacterium tuberculosis, dan penghuni rumah yang memiliki daya tahan tubuh yang kurang maka akan langsung dengan mudah diserang oleh bakteri TB. Daya tahan tubuh yang berkurang dipengaruhi oleh usia yang bertambah dan beban pekerjaan yang berat yang mana pada kelompok kasus sebagian besar responden berumur > 40 tahun dengan pekerjaan sebagai petani.

6. Hubungan Kepadatan Hunian dengan Kejadian TB Paru

Berdasarkan tabel 13 diketahui dari 30 responden yang hasil TB Paru, sebanyak 23 responden $(74,2 \%)$ yang kepadatan hunian rumahnya tidak memenuhi syarat dan sebanyak 7 responden $(24,1 \%)$ yang kepadatan hunian rumahnya memenuhi syarat. Hasil uji statistik diperoleh nilai $p$ value $=0,000(p<$ $0,05)$ hal ini berarti berarti $\mathrm{H}_{a}$ diterima dan $\mathrm{H}_{0}$ ditolak serta ada hubungan yang signifikan antara kepadatan hunian dengan kejadian TB Paru di Wilayah Kerja Puskesmas Kumun Tahun 2020.

Menurut analisa peneliti, responden yang menderita TB Paru yaitu pada kelompok kasus sebagian besar terjadi pada rumah yang kepadatan huniannya tidak memenuhi syarat. Hal ini disebabkan kepadatan hunian yang tidak memenuhi syarat akan berpengaruh terhadap kadar oksigen dalam ruangan tersebut, begitu juga kadar uap air dan suhu udaranya akibat dari jumlah penghuni rumah yang banyak. Dengan meningkatnya kadar $\mathrm{CO}_{2}$ di udara dalam rumah, maka akan memberi kesempatan tumbuh dan berkembang biak lebih bagi Mycobacterium tuberculosis sehingga semakin banyak kuman yang terhisap oleh penghuni rumah melalui saluran pernafasan.

\section{KESIMPULAN}

Dari hasil penelitian yang dilakukan pada 30 responden yang menderita TB Paru (kelompok kasus) dan 30 responden yang tidak menderita TB Paru (kelompok kontrol) di Wilayah Kerja Puskesmas Perawatan Kumun Sungai Penuh Tahun 2020 dan dari pembahasan yang telah diuraikan sebelumnya, maka dapat ditarik beberapa kesimpulan yaitu :

1. Lebih dari separuh responden yang pencahayaan rumahnya tidak memenuhi syarat di Wilayah Kerja Puskesmas Kumun Sungai Penuh Tahun 2020.

2. Lebih dari separuh responden yang kelembaban rumahnya tidak baik di Wilayah Kerja Puskesmas Kumun Sungai Penuh Tahun 2020.

3. Lebih dari separuh responden yang luas ventilasi rumahnya tidak memenuhi syarat di Wilayah Kerja Puskesmas Kumun Sungai Penuh Tahun 2020..

4. Lebih dari separuh responden yang jenis lantai rumahnya tidak memenuhi syarat di Wilayah Kerja Puskesmas Kumun Sungai Penuh Tahun 2020..

5. Lebih dari separuh responden yang jenis dinding rumahnya permanen di 
Wilayah Kerja Puskesmas Kumun Sungai Penuh Tahun 2020.

6. Lebih dari separuh responden yang kepadatan hunian rumahnya tidak memenuhi syarat di Wilayah Kerja Puskesmas Kumun Sungai Penuh Tahun 2020.

7. Terdapat hubungan yang signifikan antara pencahayaan dengan kejadian TB Paru di Wilayah Kerja Puskesmas Kumun Sungai Penuh Tahun 2020.

8. Terdapat hubungan yang signifikan antara kelembaban dengan kejadian TB Paru di Wilayah Kerja Puskesmas Kumun Sungai Penuh Tahun 2020.

9. Terdapat hubungan yang signifikan antara luas ventilasi dengan kejadian TB Paru di Wilayah Kerja Puskesmas Kumun Sungai Penuh Tahun 2020.

10. Tidak ada hubungan yang signifikan antara jenis lantai dengan kejadian TB Paru di Wilayah Kerja Puskesmas Kumun Sungai Penuh Tahun 2020.

11. Tidak ada hubungan yang signifikan antara jenis dinding dengan kejadian TB Paru di Wilayah Kerja Puskesmas Kumun Sungai Penuh Tahun 2020.

12. Terdapat hubungan yang signifikan antara kepadatan hunian dengan kejadian TB Paru di Wilayah Kerja Puskesmas Kumun Sungai Penuh Tahun 2020.

13. Faktor resiko yang paling berpengaruh terhadap kejadian TB Paru pada penelitian ini berdasarkan nilai OR tertinggi adalah kepadatan hunian, kemudian pencahayaan, luas ventilasi, dan kelembaban.

\section{SARAN}

Berdasarkan kesimpulan yang didapat dari hasil penelitian maka peneliti menyarankan kepada:

\section{Bagi Puskesmas}

Melalui pimpinan puskesmas diharapkan kepada pihak Puskesmas Perawatan Siulak Gedang khususnya bagi tenaga kesehatan yang bertugas sebagai penanggungjawab dalam pengendalian TB Paru agar selalu memberikan penyuluhan kesehatan tentang TB Paru, cara penularan TB Paru, pengobatan TB Paru serta tentang lingkungan fisik rumah yang berhubungan dengan kejadian TB Paru pada masyarakat sehingga masyarakat lebih memperhatikan kondisi fisik rumah yang baik bagi kesehatan mereka.

Diharapkan kepada masyarakat untuk memperhatikan kondisi fisik rumah yang baik bagi kesehatan seperti pencahayaan rumah yang minimal 20\% x luas lantai, kelembaban rumah yang dilihat dari ventilasi cukup, lantai kedap air, sambungan pondasi dengan dinding harus kedap air, atap tidak bocor, drainase dan saluran air disekeliling rumah baik, luas ventilasi rumah yang minimal $10 \%$ $x$ luas lantai, kondisi lantai yang kedap air, mudah dibersihkan, tidak berdebu dan tidak lembab, kondisi dinding rumah yang permanen sehingga mudah dibersihkan dari debu dan kotoran, serta kepadatan hunian yang perlu diperhatikan adalah kebutuhan ruangan $9 \mathrm{M}^{2}$ per orang, ketinggian langit-langit 2,8 $\mathrm{M}$ dan kamar tidur minimum 2 orang.

2. Bagi Institusi Pendidikan

Hasil penelitian ini diharapkan dapat memberikan informasi dan pengetahuan ilmiah yang bermanfaat dalam pengembangan ilmu pengetahuan dan penelitian selanjutnya tentang faktor-faktor yang berhubungan dengan kejadian TB Paru.

3. Bagi Peneliti Selanjutnya

Untuk peneliti selanjutnya
diharapkan dapat melakukan
penelitian secara lebih mendalam lagi
tentang faktor-faktor yang
berhubungan dengan kejadian TB Paru
seperti faktor sosial ekonomi dan


faktor lainnya, peneliti selanjutnya juga dapat melakukan penelitian tentang pengaruh beberapa variabel dengan kejadian TB Paru.

\section{DAFTAR PUSTAKA}

Arifin, M. (2009). Rumah Sehat. Diakses dari https://www.scribd.com/doc/37 715533/RumahSehat. Page 1-13. 08/09/2020

Badan Pusat Statistik. 2014. Kajian Pustaka TB Paru. Katalog BPS, XXXIII(2), 81-87. Dikases dari http://doi.org/10.1007/s13398014-0173-7.2. (30/08/2020)

Dawile, Sondakh, Maramis. (2013). Hubungan Antara Kondisi Fisik Rumah Dengan Kejadian Tuberkulosis Paru di Wilayah Kerja Puskesmas Tobelo Kabupaten Halmahera Utara. Fakultas Kesehatan Masyarakat Universitas Sam Ratulangi.

Dinas Kesehatan Provinsi Jambi. (2013). Profil Kesehatan Provinsi Jambi Tahun 2016. Jambi

Dinas Kesehatan Provinsi Jambi. (2015). Profil Kesehatan Provinsi Jambi Tahun 2018. Jambi

Fatimah, S. (2008). Faktor Kesehatan Lingkungan Rumah Yang Berhubungan Dengan Kejadian $T b$ Paru Di Kabupaten Cilacap (Kecamatan: Sidareja, Cipari, Kedungreja, Patimuan, Gandrungmangu, Bantarsari) Tahun 2008. Jurnal Kesehatan Undip.

Harfadhilah, Noor dan Sunarka. (2012). Analisa Faktor Risiko Lingkungan Terhadap Kejadian Tuberkulosis Paru, Program Studi Pendidikan Dokter UHO Bagian Kimia Bahan Alam Prodi Farmasi UHO Bagian Patologi Klinik UHO. Page 7-13. Hilman. (2004). Buku Ajar TB Paru.
Dikases dari http://Scribt/270896470-BukuAjar-Tuberkulosis. (30/08/2020)

Icha Nisa. (2013). Segitiga Epidemiologi. Diakses dari https://www.scribd.com/doc/13 6220299/segitiga-Epidemiologi. 09/10/2020.

Kemenkes RI. (2014). Pedoman Nasional Penanggulangan TB. Direktorat jendral Pengendalian Penyakit dan Penyehatan Lingkungan. Jakrata

Kurniasari, R. A. S., suhartono, suhartono, \& Cahyo, K. (2012). Faktor Risiko Kejadian Tuberkulosis Paru di Kecamatan Baturetno Kabupaten Wonogiri. Media Kesehatan Masyarakat Indonesia, 11(2), 198-204. Retrieved from http://www.ejournal.undip.ac.id /index.php/mkmi/article/view/5 396

Maharadika. (2016). Konsep Dasar, Tahapan Dan Tugas Perkembangan Masa Dewasa.

Melorose, at all. (2015). Definisi Penyakit Menular. Statewide Agricultural Land Use Baseline 2015, 1. Http://Doi.Org/10.1017/Cbo9781 107415324.004

Muaz, F. (2014). Skripsi Faktor-Faktor Yang Mempengaruhi Kejadian Tuberkulosis Paru Bta Positif Di Puskesmas Wilayah Kecamatan Serang Kota Serang Tahun 2014, Program Studi Pendidikan Dokter Fakultas Kedokteran Dan Ilmu Kesehatan Universitas Islam Negeri Syarif Hidayatullah Jakarta. page 1-2.

Notoatmodjo, S. (2007). Metode Penelitian Kesehatan. Rineka Cipta. Jakarta.

Puskesmas Kumun Sungai Penuh. 2020. Laporan Puskesmas Kumun Sungai 
Penuh. Kota Sungai Penuh

Putra Niko Rianda. (2011). Hubungan Perilaku Dan Kondisi Sanitasi Rumah Dengan Kejadian Tb Paru Di Kota Solok Tahun 2011. Program Studi Ilmu Kesehatan Masyarakat Fakultas Kedokteran Universitas Andalas. Padang.

Riyanto, Agus. (2011). Aplikasi Metodologi Penelitian Kesehatan. Nuha Medika. Yogyakarta.

Sianturi Ruslantri. (2013). Analisis Faktor Yang Berhubungan Dengan Kekambuhan Tb Paru (Studi Kasus Di Bpkm Semarang Tahun 2013). Jurusan Ilmu Kesehatan Masyarakat Fakultas IImu Keolahragaan Universitas Negeri Semarang 2013. page 1-148

Siregar, Hasan, Ashar. (2012). Hubungan Karakteristik Rumah Dengan Kejadian Penyakit Tuberkulosis Paru Di Puskesmas Simpang Kiri Kota Subulussalam Tahun 2012. Program Sarjana Fakultas Kesehatan Masyarakat Universitas Sumatera Utara Departemen Kesehatan Lingkungan. Universitas Sumatera Utara, Medan.

Sudiantara, dkk. (2012). Faktor-Faktor Yang Mempengaruhi Peningkatan Kasus Tb Paru.

Susila \& Suyanto. (2015). Metodologi Penelitian Cross Sectional. BOSSSCRIBT. Klaten Selatan. 